\title{
Antioxidant activity of thymol essential oil and inhibition of polyphenol oxidase enzyme: a case study on the enzymatic browning of harvested longan fruit
}

\author{
Muhammad Rafiullah Khan ${ }^{1 *}\left(\mathbb{0}\right.$, Chongxing Huang ${ }^{1 *}$, Hui Zhao ${ }^{1}$, Haohe Huang ${ }^{1}$, Liu Ren ${ }^{1}$, Muhammad Faiq ${ }^{2}$, \\ Majid Suhail Hashmi ${ }^{2}$, Bo Li ${ }^{1}$, Dantong Zheng ${ }^{1}$, Yangfan $\mathrm{Xu}^{1}$, Hongxia Su${ }^{1}$ and Jiejie An ${ }^{1}$
}

\begin{abstract}
Background: Enzymatic browning and microbial decay are the primary concerns that limit the postharvest life of longan fruit. These factors can be effectively prevented by sulfur dioxide $\left(\mathrm{SO}_{2}\right)$ fumigation; however, due to the safety and regulatory issues of $\mathrm{SO}_{2}$, other alternatives must be tested. In this study, antioxidant and antimicrobial activities of thymol were determined against the pericarp browning and decay of longan fruit. A simple, cost-effective method was designed for its controlled release. Thymol vapors were obtained from the slurry prepared from $5 \mathrm{~g}$ of thymol in $5 \mathrm{~mL}$ of distilled water in a 180-mL glass jar, hermetically sealed and allowed for $24 \mathrm{~h}$ to accumulate the vapors in the headspace. Fruits were packed in polyethylene packages and fumigated with thymol through a septum. Non-fumigated fruits served as control and all the packages were stored at $25 \pm 2{ }^{\circ} \mathrm{C}$ for 8 days.

Results: Thymol significantly $(P \leq 0.05)$ retarded pericarp browning $(B \mid)$, delayed the decay incidence $(\mathrm{DI})$ and maintained high color values of longan pericarp. Thymol also retained high total phenolic (TPC) and total flavonoid (TFC) contents, inhibited polyphenol oxidase (PPO) and peroxidase (POD) activities than those in control. A high coefficient of correlation of PPO with BI $(r=0.86), L^{*}(r=-0.94)$, weight loss $(r=0.93)$, TPC $(r=-0.77)$, TFC $(r=-0.80)$, DI $(r=0.92)$ and many other quality and color parameters indicated the antioxidant efficacy of thymol. Longer shelf life of 8 days with good quality attributes was obtained in thymol-treated fruits than 6 days in control.
\end{abstract}

Conclusion: Thymol could be effectively used as a natural antioxidant for a wide range of fruits.

Keywords: Longan, Fruit, Thymol, Essential oil, Antioxidant, Antimicrobial, Enzymatic browning, Polyphenol oxidase

\section{Background}

Due to the potential health benefits, fruits are the important part of human nutrition [1]. Longan (Dimocarpus longan Lour) is a non-climacteric fruit widely cultivated in many countries, including China, Thailand, Vietnam. Due to its sweet and delicate taste, longan is preferred to be eaten fresh. Furthermore, longan fruit is a rich

\footnotetext{
*Correspondence: khan87@gxu.edu.cn; huangcx21@163.com ${ }^{1}$ School of Light Industry and Food Engineering, Guangxi University, Nanning 530004, China

Full list of author information is available at the end of the article
}

repository of several bioactive compounds with antimicrobial, antioxidant, anti-carcinogenic and anti-inflammatory effects; therefore, longan is used in traditional medicine in several ailments in Asia [2, 3]. However, pericarp browning, microbial decay and skin desiccation are the limiting factors of longan fruit that shortened its postharvest life to 2-4 days at ambient temperature [4]. Pericarp browning of longan fruit has been attributed to the oxidation of phenolic compounds by the polyphenol oxidase (PPO) enzyme. In addition, high moisture and sugar contents cause the longan fruit more vulnerable 
to microbial growth. To date, the fruit's postharvest life has been preserved by treating with butanol [5], antibrowning agent solutions [6], fumigation with hexanal vapors [7] and chlorine dioxide fumigation [8-10] and many others. Currently, the awareness of the consumers towards the safe fruits and possible residues of the synthetic compounds in fruits, other feasible alternatives should be researched that must be safe and effective in preventing the browning and decay of longan fruit.

Essential oils are plant-based extracts and comprise a number of volatile and secondary metabolites that have shown a direct activity against phytopathogens and enhance the plant defence system against these microorganisms [11, 12]. Essential oils (EOs) have been tapped mainly for their flavor and fragrances and various biological characteristics such as antioxidant and antimicrobial. The main components are terpenes, sesquiterpenes and several derivative compounds (alcohols, aldehydes, ketones, acids, phenols, ethers, esters, amines, amides, heterocycles, etc.), which are responsible for the characteristic odor and flavor [13]. Furthermore, essential oil components mainly belong to the terpene family and several compounds in this family have been identified [14]. These compounds include functionalized derivatives of alcohols (geraniol, $\alpha$-bisabolol), ketones (menthone, $p$-vetivone) of aldehydes (citronellal, sinensal), esters ( $\gamma$-terpinyl acetate, cedryl acetate), and phenols (thymol) [15]. The presence of these compounds and their main components gives them different functional properties, which could be considered for many food applications $[16,17]$.

The genus Thymus from the Lamiaceae family is commonly used for food, cosmetic, and medicinal purposes. A thyme herb obtained from Thymus vulgaris and Thymus zygis is a well-known herbal substance in different industries. Thyme EO compounds belong to various chemical groups, including monoterpenes, monoterpene alcohols, phenol derivatives, ketones, aldehydes, ethers and esters. There are also numerous chemotypes within the T. vulgaris species, differing in the main component of EO. The main components of thyme EO are the isomeric phenolic monoterpenes thymol (2-isopropyl-5-methylphenol) and carvacrol (2-methyl-5-(propan2 -yl)phenol) [18, 19]. The study by Sellamuthu et al. [20] showed that out of 26 components in thymol oil, thymol (53.19\% RA) was the major compound, followed by cymol (20.68\% RA). Thymol is a colorless, crystalline compound with a strong odor and solubility in alcohol and other organic solvents, but only slightly soluble in water. Thymol possess antiseptic, antibacterial, antifungal, anthelmintic, antiviral, antioxidant, expectorant, antispasmodic, carminative, diaphoretic, sedative, antirheumatic, and even anti-cancer, anti-hyperlipidemic and anti-hyperglycemic action [21-23]. Thymol is generally recognized as a safe (GRAS) compound for food ingredients as long as the concentration does not exceed $50 \mathrm{mg} /$ $\mathrm{kg}$ [24].

Previous studies revealed that essential oil either alone or in combination with other compounds successfully extended the shelf life of various fruits such as lemon [25], strawberries [26, 27], sweet cherry [28], table grapes $[29,30]$ and purple yam [31]. In our previous study, we coated the longan fruit with thymol to prevent browning and decay [6]; however, a peculiar taste was detected during the sensory evaluation of the fruit. Therefore, this experiment was designed to find the best possible and feasible method to preserve the postharvest life of longan fruits. A very simple, cost-effective and feasible method was proposed for thymol fumigation. Basic quality tests were conducted to identify the mechanism and mode of action of thymol in preventing the enzymatic browning and microbial decay of longan fruit.

\section{Materials and methods \\ Reagents}

Gallic acid, (+)-catechin, 4-methylcatechol, polyvinylpyrrolidone (PVP), guaiacol, bovine serum albumin, Coomassie brilliant blue G-250 and food grade thymol were purchased from Sigma Chemical Co. (St. Louis, MO, USA). Folin-Ciocalteu's phenol reagent, phosphoric acid and hydrogen peroxide were obtained from Merck Darmstadt, Germany.

\section{Thymol fumigation and fruit treatment}

A new, simple and cost-effective fumigation method was designed to find the best possible and effective preservative method for fresh longan as an alternative to $\mathrm{SO}_{2}$ fumigation. The chemical structure and a schematic diagram of thymol fumigation are shown in Fig. 1 and Graphical Abstract, respectively. Thymol (>99\% food grade) $5 \mathrm{~g}$ was mixed with $5 \mathrm{~mL}$ distilled water in a 180 $\mathrm{mL}$ glass jar to make a slurry. The jar was hermetically sealed and allowed to stand for $24 \mathrm{~h}$. This method was optimized based on the various trials to get a constant concentration of thymol vapors in the jar. Longan cv. Daw fruit of uniform color and size were prepared with a $5-\mathrm{mm}$ stalk and about $200 \mathrm{~g}$ of fruit were heat-sealed in polyethylene (PE) packages. Then $15 \mathrm{~mL}$ of thymol

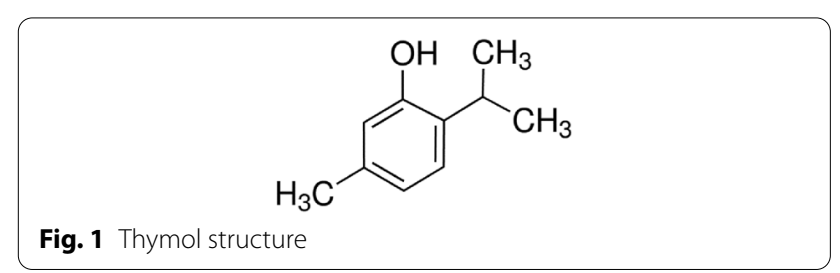


vapors were withdrawn from the jar and injected into PE packages through the septum. Fruits packed in the same conditions without thymol fumigation were served as a control. All the packages were stored at ambient temperature at $25 \pm 2{ }^{\circ} \mathrm{C}$ for 8 days. Different quality parameters were evaluated at 0 -day and 2-day intervals. From each treatment, three replicates (packages) were used on each sampling day for analysis.

\section{Quality evaluation tests Weight loss}

Weight loss was determined by weighing the fruit on day 0 and every 2nd day and the results were expressed in percentage.

\section{Decay incidence}

Decayed fruit was defined as any fruit showing visible symptoms of fungal growth or other decay symptoms on the surface. Fruit decay was visually evaluated, the number of decayed fruit was counted and then the decay percentage from the total fruit was calculated by the following formula [32]:

$$
\text { Percentage of fruit decay }=\frac{\text { Number of decayed fruit }}{\text { Total number of fruit }} \times 100 \text {. }
$$

\section{Pericarp browning and pericarp color}

Pericarp browning index (BI) of longan fruit was determined by observing the amount of total brown area on each fruit surface: $1=1 \%$ (no browning), $2=1-10 \%$ (slight browning), $3=>10-25 \%$ (moderate browning), $4=>25-50 \%$ (severe browning) and $5=>50 \%$ (complete browning) and calculated using the following equation [33]. Fruit with a browning scale above 3 was the limit of market acceptability:

\section{Total phenolic and flavonoids contents}

Phenolic and flavonoid contents were extracted from the liquid nitrogen-frozen pericarps of 8 fruits and stored at $-20{ }^{\circ} \mathrm{C}$, according to the method of Khan et al. [33]. Reaction mixtures for total phenolic contents (TPC) and total flavonoid contents (TFC) were prepared according to the methods of Khan et al. [33] and Dewanto et al. [34], respectively, using a UV-visible spectrophotometer (Biochrom Libra S22, Cambridge, UK). Results for TPC and TFC were expressed as milligram of gallic acid per $\mathrm{kg}(\mathrm{ppm})$ and milligram of catechin per $\mathrm{kg}(\mathrm{ppm})$ of fresh weight, respectively. The experiments were done in triplicate.

\section{Enzymes activities}

For determining the anti-browning effects of thymol on the inhibition of enzyme activities, pericarps of 8 fruits from each treatment were ground in liquid nitrogen and sieved from mesh no. 30 with aperture $600 \mu \mathrm{m}$ (Retsch, D5657, Hann. Munden, Germany). About $5.0 \mathrm{~g}$ of the ground powder was homogenized (Ultra-Turrax T25 homogenizer, Staufen, Germany) in the presence of $20 \mathrm{~mL} 0.05 \mathrm{M}$ sodium phosphate buffer $(\mathrm{pH} 7)$ and $0.5 \mathrm{~g}$ of polyvinylpyrrolidone (PVP) for $2 \mathrm{~min}$. Homogenate was centrifuged (Sorvall RC6 + Centrifuge, Osterode, Germany) for $20 \mathrm{~min}$ at $19,000 \times g$ and $4{ }^{\circ} \mathrm{C}$. The supernatant was collected as the crude enzyme extract [35].

Polyphenol oxidase (PPO) activity was assayed using $0.5 \mathrm{~mL}$ of $100 \mathrm{mM}$ 4-methylcatechol, $1 \mathrm{~mL}$ of $0.05 \mathrm{M}$ sodium phosphate buffer $(\mathrm{pH} 7)$ and $0.5 \mathrm{~mL}$ of enzyme extract [36]. The absorbance was recorded at $410 \mathrm{~nm}$ for 5 min using a UV-visible spectrophotometer (Biochrom Libra S22, Cambridge, UK). One unit of enzyme activity was defined as the amount that caused a change

$$
B I=\sum \frac{\text { Browning level } \times \text { number of fruit at each browning level }}{\text { Total number of fruit in the treatment }}
$$

Pericarp color $\left(\mathrm{L}^{*}, \mathrm{a}^{*}, \mathrm{~b}^{*}\right)$ was measured using Minolta CR-310 colorimeter (Minolta, Tokyo, Japan) and chroma $\left(C^{*}\right)$ and hue $\left(h^{\circ}\right)$ were calculated by the following equations:

$$
\begin{aligned}
& C^{*}=\left(a^{* 2}+b^{* 2}\right)^{1 / 2}, \\
& h^{\circ}=\tan ^{-1} \frac{b^{*}}{a^{*}} .
\end{aligned}
$$

of 0.001 in the absorbance per min.

Peroxidase (POD) activity was determined using guaiacol as a substrate [37] and the absorbance was recorded for $2 \mathrm{~min}$ at $470 \mathrm{~nm}$ using a UV-visible spectrophotometer (Biochrom Libra S22, Cambridge, UK). One unit of enzyme activity was defined as the amount that caused a change of 0.01 in the absorbance per min. Protein contents were determined according to the dye-binding method [38]. Enzymes (PPO and POD) activities were expressed as units $\mathrm{min}^{-1} \mathrm{mg}^{-1}$ protein. 
Each replicate was analyzed 3 times and their mean was used for statistical analysis.

\section{Statistical analysis}

Data were subjected to the analysis of variance (ANOVA) using SPSS (SPSS incorporation Chicago, IL, USA). Duncan's multiple tests were performed to determine the significant difference $(P \leq 0.05)$ among the treatments. The correlation analysis was carried out in Microsoft Excel 2019.

\section{Results}

\section{Weight loss, decay incidence and pericarp browning}

Weight loss of longan fruit increased with storage time in both treated and control packages (Fig. 2). No significant difference $(P>0.05)$ was found in control and treated longan packages during storage until day 4 . Weight loss at day 6 was significantly high in control than that in thymol-treated fruit. Decay incidence (DI) enhanced greatly in control fruit than that in thymol-treated fruit (Fig. 3). No DI was found at day 2 in both treatments, while at days 4 and 6 , control fruit had significantly $(P \leq 0.05)$ high DI than that in thymol-treated fruit. Pericarp browning (BI) increased in both treatments during storage (Fig. 4). BI was significantly $(P \leq 0.05)$ higher in the control treatment compared to thymol treatment from day 2 onward.

\section{Color $\left(\mathrm{L}^{*}, \mathrm{a}^{*}, \mathrm{~b}^{*} \mathrm{C}^{*}\right.$ and $\left.\mathrm{h}^{\circ}\right)$ values}

The color values of longan fruit decreased with storage time. The color values and pictures of longan are presented in Table 1 and Fig. 5, respectively. No significant difference was found at day 0 ; however, from

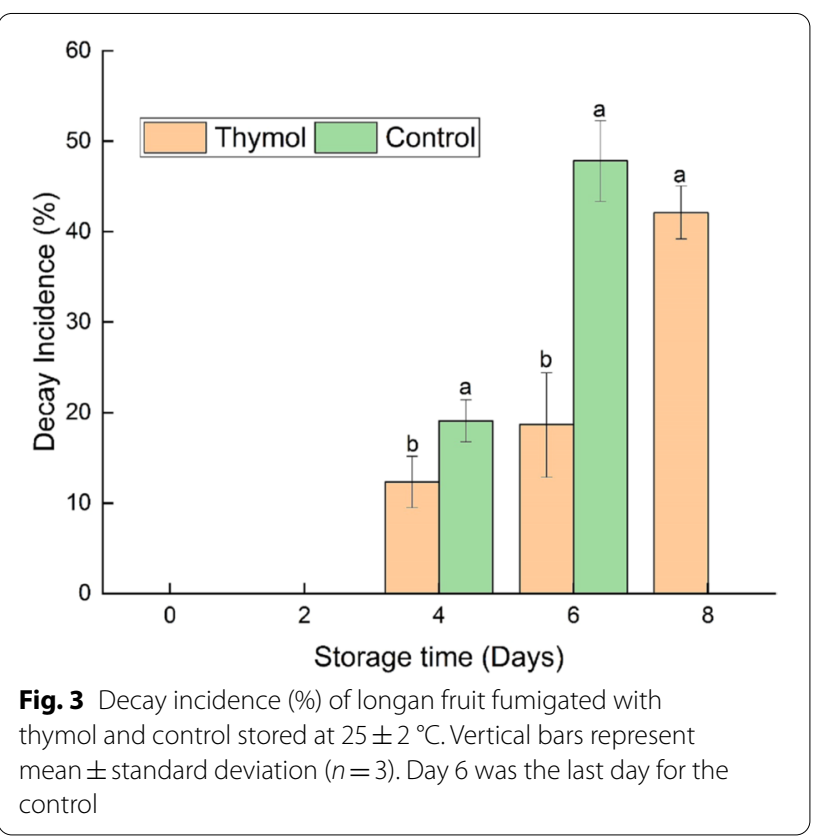

days 2 to 6, thymol-treated fruit has significantly higher $(\mathrm{P} \leq 0.05) \mathrm{L}^{*}$ values than control fruit. A decrease in $\mathrm{L}^{*}$ values was associated with the browning index, which can also be seen from the high correlation $(r=-0.96$; Fig. 6) between the $L^{*}$ and BI. a* values increased in both treatments; however, no significant difference $(P>0.05)$ was found during storage (Table 1$). b^{*}$ and $C^{*}$ values decreased with storage time in both treatments, and no significant $(P>0.05)$ difference was found until day 4 ; however, at day 6 , thymol-treated fruit had high

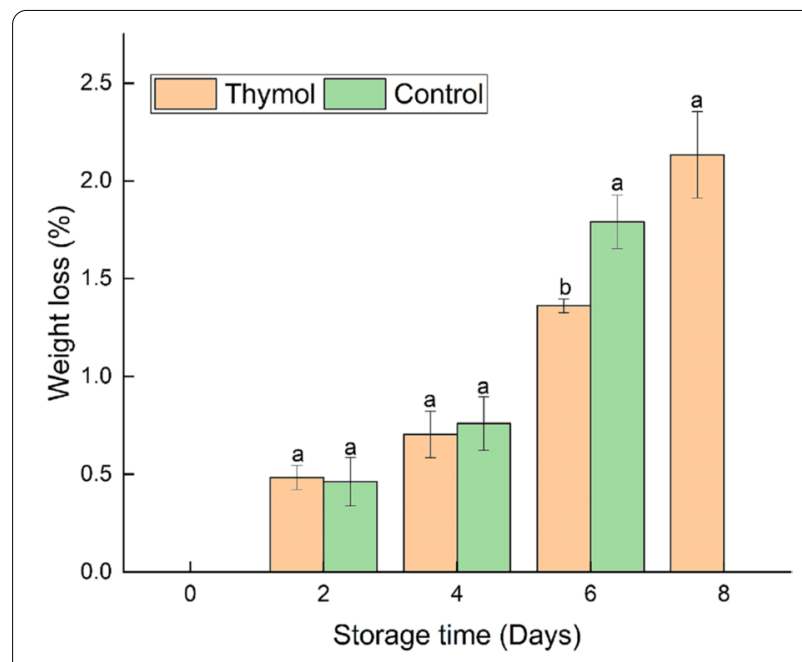

Fig. 2 Weight loss (\%) of longan fruit fumigated with thymol and control stored at $25 \pm 2{ }^{\circ} \mathrm{C}$. Vertical bars represent mean \pm standard deviation $(n=3)$. Day 6 was the last day for the control

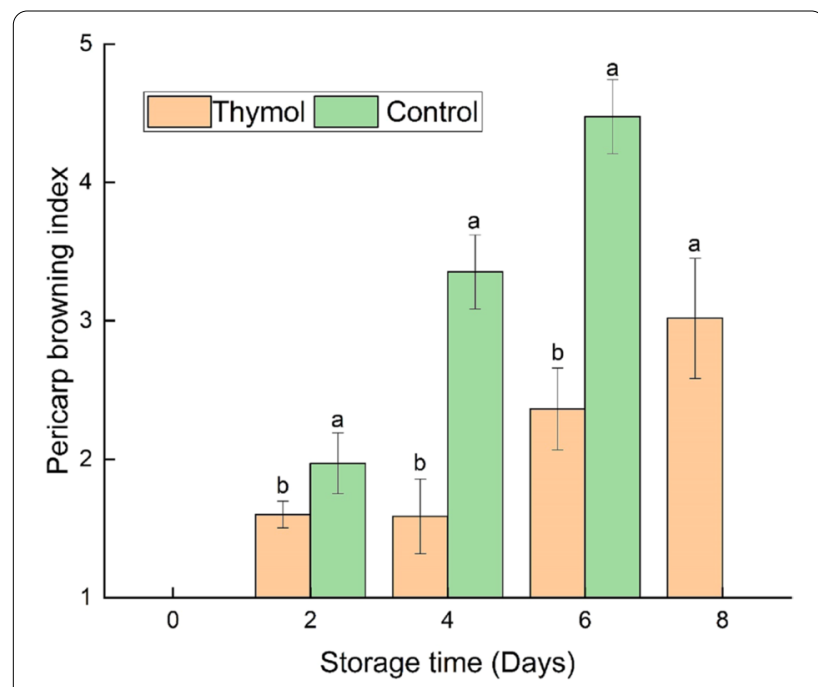

Fig. 4 Pericarp browning of longan fruit fumigated with thymol and control stored at $25 \pm 2{ }^{\circ} \mathrm{C}$. Vertical bars represent mean \pm standard deviation $(n=3)$. Day 6 was the last day for the control 
Table 1 Color values of longan pericarp fumigated with thymol and control stored at $25 \pm 2{ }^{\circ} \mathrm{C}$

\begin{tabular}{|c|c|c|c|c|c|c|}
\hline & \multirow[t]{2}{*}{ Treatments } & \multicolumn{5}{|c|}{ Storage time (days) } \\
\hline & & 0 & 2 & 4 & 6 & 8 \\
\hline \multirow[t]{2}{*}{$L^{*}$} & Thymol & $64.84 \pm 1.29 a$ & $65.62 \pm 4.57 a$ & $57.31 \pm 0.72 a$ & $55.62 \pm 2.48 a$ & $42.62 \pm 1.18 a$ \\
\hline & Control & $63.01 \pm 1.67 a$ & $59.75 \pm 3.88 b$ & $51.15 \pm 2.31 b$ & $39.60 \pm 4.99 b$ & - \\
\hline \multirow[t]{2}{*}{$a^{*}$} & Thymol & $0.99 \pm 0.60 a$ & $1.83 \pm 0.37 a$ & $1.69 \pm 0.56 a$ & $2.82 \pm 0.67 a$ & $5.09 \pm 0.35 a$ \\
\hline & Control & $1.22 \pm 0.18 a$ & $1.56 \pm 0.11 \mathrm{a}$ & $2.34 \pm 0.58 a$ & $3.07 \pm 1.25 \mathrm{a}$ & - \\
\hline \multirow[t]{2}{*}{$b^{*}$} & Thymol & $38.32 \pm 0.69 a$ & $36.47 \pm 2.76 a$ & $30.68 \pm 1.43 a$ & $28.65 \pm 1.78 a$ & $19.80 \pm 0.80 \mathrm{a}$ \\
\hline & Control & $38.20 \pm 0.68 a$ & $32.54 \pm 1.24 a$ & $27.90 \pm 1.28 a$ & $17.18 \pm 1.81 b$ & - \\
\hline \multirow[t]{2}{*}{$C^{*}$} & Thymol & $38.35 \pm 0.69 a$ & $36.52 \pm 2.74 a$ & $30.74 \pm 1.47 a$ & $28.81 \pm 1.82 \mathrm{a}$ & $20.47 \pm 0.76 a$ \\
\hline & Control & $38.22 \pm 0.68 a$ & $32.59 \pm 1.24 a$ & $28.02 \pm 1.29 a$ & $17.48 \pm 1.98 \mathrm{~b}$ & - \\
\hline \multirow[t]{2}{*}{$h^{\circ}$} & Thymol & $88.48 \pm 0.88 a$ & $87.07 \pm 0.72 \mathrm{a}$ & $86.87 \pm 0.96 a$ & $84.35 \pm 1.10 a$ & $75.30 \pm 0.94 a$ \\
\hline & Control & $88.18 \pm 0.26 a$ & $87.29 \pm 0.22 a$ & $85.02 \pm 1.27 a$ & $79.69 \pm 2.92 \mathrm{a}$ & - \\
\hline
\end{tabular}

$\mathrm{a}, \mathrm{b} .$. in each column characterize the significant difference among treatments at $P \leq 0.05,(n=9)$.

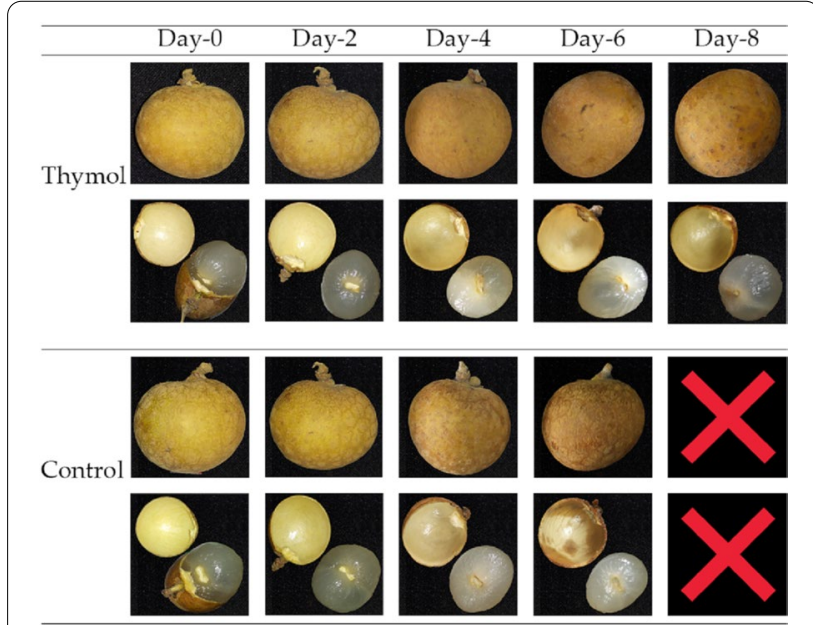

Fig. 5 Pictures of longan pericarp and flesh fumigated with thymol and control stored at $25 \pm 2{ }^{\circ} \mathrm{C}$. Day 6 was the last day for the control

$(P \leq 0.05) \mathrm{b}^{*}$ and $\mathrm{C}^{*}$ values than that in the control treatment (Table 1). Hue $\left(h^{\circ}\right)$ angle declined in both treatments with storage time with no significant differences (Table 1).

\section{Total phenolic and total flavonoid contents}

Total phenolic content (TPC) in longan pericarp in treated and non-treated fruit is presented in Fig. 7. No significant difference $(P>0.05)$ was found in both treatments until day 2 . On days 4 and 6 , the control fruit exhibited a significant $(P \leq 0.05)$ reduction in the TPC and TFC contents compared to the treated fruit (Fig. $7 \mathrm{~A}$ and $\mathrm{B})$.

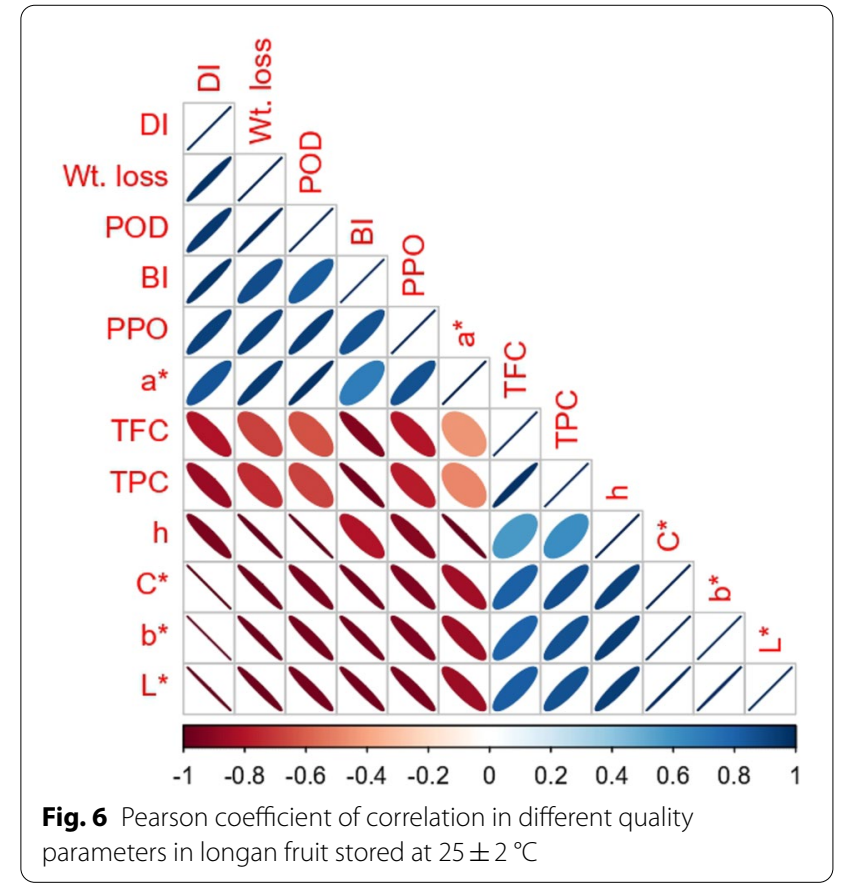

\section{Enzymes activities}

Polyphenol oxidase (PPO) activity increased in both treatments with storage time. PPO activity was significantly higher $(P \leq 0.05)$ in control from day 0 to day 6 than that in thymol-treated fruit (Fig. 8a). Peroxidase activity in longan pericarp increased during storage, reached the maximum at day 2 in control, and gradually declined (Fig. 8b). 


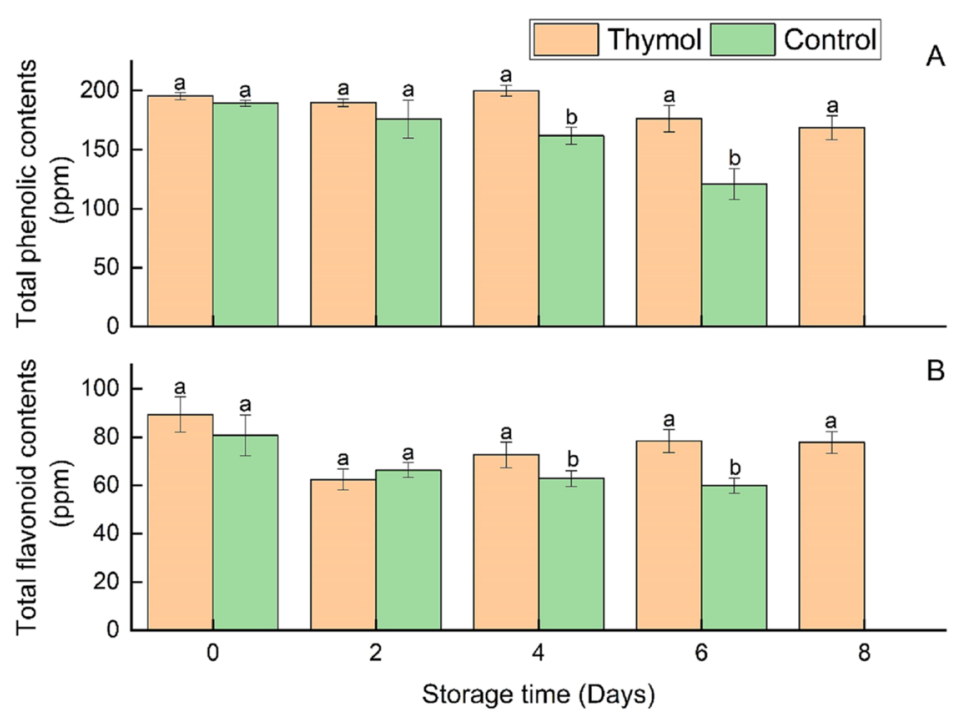

Fig. 7 Total phenolic (A) and total flavonoid contents (B) in longan fruit fumigated with thymol and control stored at $25 \pm 2{ }^{\circ} \mathrm{C}$. Vertical bars represent mean \pm standard deviation $(n=3)$. Day 6 was the last day for the control

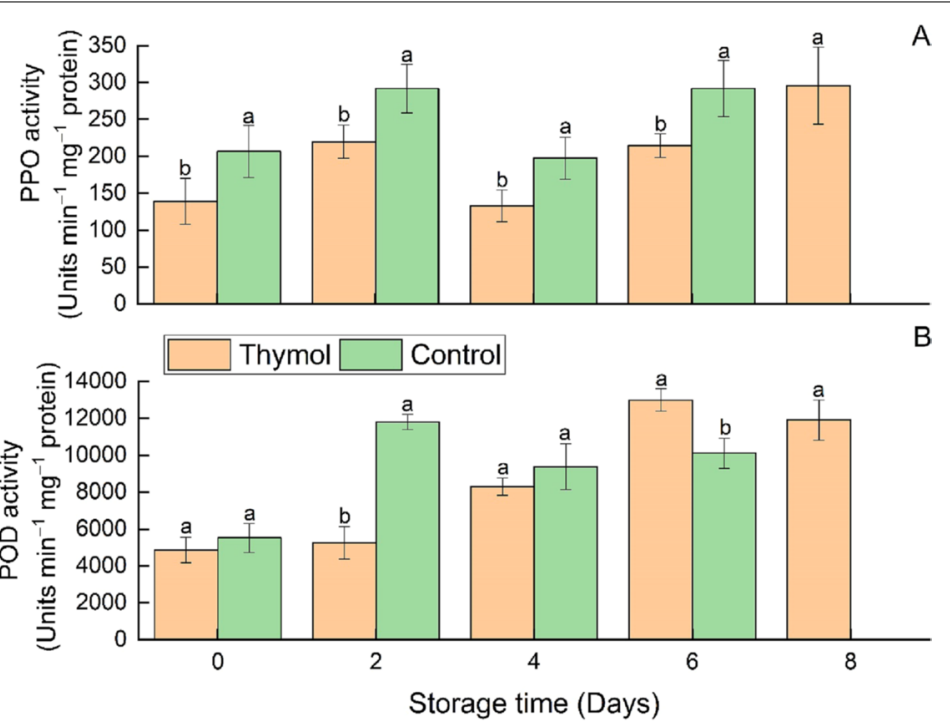

Fig. 8 Polyphenol oxidase (PPO) (A) and peroxidase (POD) (B) activities in longan fruit fumigated with thymol and control stored at $25 \pm 2{ }^{\circ} \mathrm{C}$. Vertical bars represent mean \pm standard deviation $(n=3)$. Day 6 was the last day for the control

\section{Discussion}

Packaging films effectively reduced the increase in weight loss as no difference was found until day 4 in both treatments. While at the last day of the experiment, the highest weight loss was $2.13 \%$ in thymol-treated fruit. Results from this study were in line with the work of Valverde et al. [30], who found a significant reduction in weight loss in table grapes being fumigated with thymol, menthol or eugenol under modified atmosphere packaging
(MAP) of non-perforated oriented polypropylene (N-OPP) bags compared to control (only MAP, without essential oil) and stored at $1{ }^{\circ} \mathrm{C}$ for 35 days. Geransayeh et al. [39] also reported the lowest weight loss in thymoltreated strawberries than in control and stated that a more significant reduction in weight loss was observed in the high concentration of thymol than all the low concentrations. Awad et al. [40] also observed a substantial decrease in weight loss in fresh-cut green beans when 
treated with tea tree essential oil and peppermint essential oil than the control. In the current study, we also comparatively found low weight loss in thymol-treated longan, and it can be stated that thymol could act as a barrier against water loss. Furthermore, the prevention of weight loss in longan fruits could also be attributed to the use of polymeric films as one of the benefits of the modified atmosphere packaging. The is because the differences in water pressure between the sample and surrounding air cause the sample to lose weight which could be prevented to extend the shelf life.

Compared to control, the lowest DI was found in thymol-treated longan fruits. This antimicrobial mode of action of thymol could be attributed to the disruption of cellular membrane integrity and intervention with active sites of enzymes and cellular metabolism [41]. Kowalczyk et al. [19] attributed the antifungal activity of thymol to the fatty acid metabolism in the fungal cells. This phenomenon increases the concentration of reactive oxygen species and oxidative stress and decreases the extracellular polymer matrix, and capsular polysaccharide. Poonam et al. [42] observed a decrease in the ergosterol in the membrane of Candida and Cryptococcus treated with thymol which disrupted membrane integrity, disturbed the membrane-associated enzyme, extensive damage and finally led to cell death. The hydrophobic nature of the cell membrane of pathogens is the main reason for the attraction of the essential oil. Thymol can integrate into the lipid layer of the cell membrane and enhance the surface curvature. The mechanism of antifungal activity of thymol is the interaction of the hydrophilic part of the molecules and the polar part of the membrane, while the hydrophobic benzene ring and aliphatic side chains sink into the inner part of the biological membrane. This phenomenon causes big changes in the membrane structure due to the destabilization of the lipid layer, decreased elasticity, and increased fluidity. Consequently, it increases the permeability to potassium and hydrogen ions and affects the membrane protein such as enzymes and receptors. Thymol interacts with its embedded proteins in the cell membrane and changes the conformation and protein activity through various non-specific mechanisms [19, 43]. Kryvtsova et al. [44] stated that the antimicrobial activity of thymol depends on the percentage composition of its major constituents. Essential oils with a high phenolic monoterpene percentage, mainly thymol, have the strongest antibacterial properties associated with their structure [45].

Abd-Alla et al. [46] and Meer et al. [47] stated that thyme oil vapor or volatile phase is more effective than liquid. This is because the lipophilic molecules in the aqueous phase associate form micelles that restrict essential oils' interaction with the organism, while the vapors phase makes them attractive as possible fumigants for protecting stored products [48] and suppressing the pathogens [49]. Another advantage of the vapor phase is that it is needed in very low concentration without adversely affecting the sensory characteristics of the produce [50]. Hence, in this study, thymol vapor prevented microbial growth and increased longan fruit's shelf life without affecting the sensory characteristics (data not shown). Therefore, for the longest shelf life of longan fruit, thymol vapors combined with MAP need to be practiced at low temperatures.

Prevention/or delaying of pericarp browning of longan might be attributed to the high antioxidant activity of thymol [51]. Kevin et al. [52] analyzed the antioxidant activities of the 423 essential oils from 48 families and reported that phenolic terpenes (carvacrol, thymol, and eugenol) are the major constituents of the most effective oils having the ability to scavenge free radicals. Essential oil (eugenol, thymol or menthol) significantly prevented the stem browning of cherries than in the control when $1 \mathrm{~mL}$ of each of these compounds was placed on sterile gauze and kept in polypropylene trays covered with polypropylene films, stored at $1{ }^{\circ} \mathrm{C}$ for 16 days followed by 1 day at $20^{\circ} \mathrm{C}$ [28]. Our results suggested that thymol effectively prevented the formation of brown polymer on the pericarp of the longan fruit compared to control. This can also be seen in a continuous decrease in $\mathrm{L}^{*}$ values during the whole storage and $\mathrm{b}^{*}$ and $\mathrm{C}^{*}$ at day 6 in control treatment which shows that thymol prevented the oxidation reaction and maintained the color values. High TPC and TFC contents and lower activities of PPO further revealed that thymol has a strong activity against the oxidation reaction and maintained the cell integrity, delayed senescence and thereby, prevented the mixing up the cell constituents and consequently inhibited the pericarp browning. It is well understood that upon the breakdown of the cell membrane, cell constituents such as $\mathrm{PPO}$ and its substrates (phenolic compounds) come into contact and initiate the browning reaction, thus causing browning deterioration of the product [53].

A coefficient of correlation analysis was conducted to see the association of these factors in the enzymatic reactions. Coefficient of correlation indicated that PPO was highly associated with $L^{*}(r=-0.94)$, browning index $(r=0.86)$, with TPC ( $r=-0.77$; Fig. 6). Browning index also high correlated with TPC and $\mathrm{L}^{*}(r=-0.96)$, with TFC $(r=-0.91)$ as well as with weight loss $(r=0.89)$ (Fig. 6). It can also be seen in the respective figures that the highest PPO activity (Fig. 8), lowest phenolic (Fig. 7) and highest pericarp browning (Fig. 4) were observed particularly in non-fumigated longan fruit (control).

Thymol also prevented quality deterioration and extended the shelf life of other fruits. Atress et al. [27] 
reported a high color $\left(\mathrm{L}^{*}, \mathrm{c}^{*}\right.$ and $\left.h^{\circ}\right)$ values than control (distilled water) in strawberries when treated with the mixture of thymol with soy protein or wheat protein. Valero et al. [29] stated that thymol fumigation (placing either 75 or $150 \mu \mathrm{L}$ on sterile gauze inside the bag) significantly reduced changes in color values $\left(\mathrm{L}^{*}, \mathrm{a}^{*}\right.$ and $\left.\mathrm{b}^{*}\right)$ and retained high TPC than non-treated (control) table grapes. In another study of essential oil $(0.5 \mathrm{~mL}$ of thymol, eugenol, menthol on sterile gauze inside bags) in combination with MAP on the table grapes stored at $1{ }^{\circ} \mathrm{C}$ for 35 days revealed that all the essential oils maintained the color values $\left(\mathrm{L}^{*}\right.$ and $\left.h^{\circ}\right)$ and phenolic contents than the control treatment [30]. Similarly, Geransayeh et al. [39] reported that thymol fumigation reduced the activities of the enzymes in strawberries than the control treatment stored at $4{ }^{\circ} \mathrm{C}$ for 12 days. Higher TPC was also observed in fresh-cut beans pods when treated with ethanol, ascorbic acid and essential oil than the control [40]. Liu et al. [54] treated apricot and plum with thymol essential oil and inhibited the browning of these fruits without any adverse or toxic effect.

\section{Conclusions}

In this study, a new fumigation technique was proposed. Longan fruits were fumigated with thymol vapors and stored at ambient temperature $25 \pm 2{ }^{\circ} \mathrm{C}$ for 8 days. Nonfumigated fruits were considered as control. Thymol fumigation successfully prevented the pericarp browning, inhibited decay incidence, prevented the color loss, maintained high TPC and TFC contents. Thymol treatment also slowed down the activities of the enzymes compared to control treatment. Thymol fumigation was the best alternative to thymol dipping as no peculiar flavor was found. Among essential oils, thymol is one of the registered food additives in the US Food and Drug Administration as safe for human consumption; therefore, thymol could be used a good alternative to replace $\mathrm{SO}_{2}$ fumigation at the commercial level.

\section{Acknowledgements}

The authors thank Guangxi University for providing a Postdoctoral Fellowship.

\section{Authors' contributions}

Conceptualization and design, $\mathrm{CH}$ and MRK. Methodology, MRK. Resources, LR, BL. Software, LB, DZ, YX, HS and JA. Writing-original draft, MRK. Supervision, CH. Statistical analysis, MRK, HH. Data curation, MRK and LR. Writing, review and editing, MRK, $\mathrm{HZ}, \mathrm{CH}, \mathrm{MF}$ and $\mathrm{MSH}$. Funding acquisition, $\mathrm{CH}$. All authors read and approved the final manuscript.

\section{Funding}

This research was funded by the Guangxi Science and Technology Plan Project (Project No. 2018AB45007), the Guangxi Natural Science Foundation Program (2019JJD120012) and the Postdoctoral Project of the Guangxi University.

Availability of data and materials

All available data are presented in the figures and tables.

\section{Declarations}

Ethics approval and consent to participate

Not applicable.

Consent for publication

Not applicable.

\section{Competing interests}

The authors declare no competing interests.

\section{Author details}

${ }^{1}$ School of Light Industry and Food Engineering, Guangxi University, Nanning 530004, China. ${ }^{2}$ Department of Food Science and Technology, The University of Agriculture Peshawar, Peshawar 25000, Pakistan.

Received: 3 August 2021 Accepted: 30 September 2021

Published online: 15 December 2021

\section{References}

1. Naji-Tabasi S, Emadzadeh B, Shahidi-Noghabi M, Abbaspour M, Akbari E. Physico-chemical and antioxidant properties of barberry juice powder and its effervescent tablets. Chem Biol Technol Agric. 2021;8:23. https:// doi.org/10.1186/s40538-021-00220-z.

2. Lal N, Sahu N, Jayswal DK, Diwan G, Tandon K. Traditional, medicinal and nutraceutical values of minor fruit: Longan. Curr J Appl Sci Technol. 2020;39:59-70. https://doi.org/10.9734/cjast/2020/v39i4131120.

3. Zhu X, Wang H, Sun J, Yang B, Duan X, Jiang Y. Pericarp and seed of litchi and longan fruits: constituent, extraction, bioactive activity, and potential utilization. J Zhejiang Uni Sci B. 2019;20:503-12. https://doi.org/10.1631/ jzus.B1900161.

4. Jiang Y, Zhang Z, Joyce DC, Ketsa S. Postharvest biology and handling of longan fruit (Dimocarpus longan Lour). Postharvest Biol Technol. 2002;26:241-52. https://doi.org/10.1016/S0925-5214(02)00047-9.

5. Li L, Li J, Sun J, Li C, Sheng J, Zheng F, Liao F, He X, Liu G, Ling D, You $X$. Effects of 2-butanol on quality and physiological characteristics of longan fruit stored at ambient temperature. Postharvest Biol Technol. 2015;101:96-102. https://doi.org/10.1016/j.postharvbio.2014.12.002.

6. Khan MR, Chinsirikul W, Sane A, Chonhenchob V. Combined effects of natural substances and modified atmosphere packaging on reducing enzymatic browning and postharvest decay of longan fruit. Int J Food Sci Technol. 2019;55:500-8. https://doi.org/10.1111/ijfs.14293.

7. Thavong P, Archbold DD, Pankasemsuk T, Koslanund R. Effect of hexanal vapour on longan fruit decay, quality and phenolic metabolism during cold storage. Int J Food Sci Technol. 2010;45:2313-20. https://doi.org/10. 1111/j.1365-2621.2010.02401.x.

8. Chomkitichai W, Chumyam A, Rachtanapun P, Uthaibutra J, Saengnil K. Reduction of reactive oxygen species production and membrane damage during storage of'Daw'longan fruit by chlorine dioxide. Sci Hortic. 2014;170:143-9. https://doi.org/10.1016/j.scienta.2014.02.036.

9. Chomkitichai W, Faiyue B, Rachtanapun P, Uthaibutra J, Saengnil K. Enhancement of the antioxidant defense system of post-harvested 'Daw' longan fruit by chlorine dioxide fumigation. Sci Hortic. 2014;178:138-44. https://doi.org/10.1016/j.scienta.2014.08.016.

10. Chumyam A, Shank L, Uthaibutra J, Saengnil K. Effects of chlorine dioxide on mitochondrial energy levels and redox status of Daw longan pericarp during storage. Postharvest Biol Technol. 2016;116:26-35. https://doi.org/ 10.1016/j.postharvbio.2016.01.002.

11. Ghavam M, Afzali A, Manconi M, Bacchetta G, Manca ML. Variability in chemical composition and antimicrobial activity of essential oil of Rosa $\times$ damascena Herrm from mountainous regions of Iran. Chem Biol Technol Agric. 2021;8:22. https://doi.org/10.1186/s40538-021-00219-6.

12. Khan N, Jamila N, Amin F, Masood R, Atlas A, Khan W, Ain NU, Khan SN Quantification of macro, micro and trace elements, and antimicrobial activity of medicinal herbs and their products. Arab J Chem. 2021;14: 103055. https://doi.org/10.1016/j.arabjc.2021.103055. 
13. Pourmortazavi SM, Hajimirsadeghi SS. Supercritical fluid extraction in plant essential and volatile oil analysis. J Chromatogr A. 2007;1 163:2-24. https://doi.org/10.1016/j.chroma.2007.06.021.

14. Modzelewska A, Sur S, Kumar KS, Khan SR. Sesquiterpenes: Natural products that decrease cancer growth. Curr Med Chem Anti-Cancer Agents. 2005;54:477-99. https://doi.org/10.2174/1568011054866973.

15. Dhifi W, Bellili S, Jazi S, Bahloul N, MnifW. Essential Oils'Chemical Characterization and Investigation of Some Biological Activities: A Critical Review. Medicine. 2016:3:25. https://doi.org/10.3390/medicines3040025.

16. Das G, Shin H, Kumar A, Vishnuprasad CN, Patra JK. Photo-mediated optimized synthesis of silver nanoparticles using the extracts of outer shell fibre of Cocos nucifera L. fruit and detection of its antioxidant, cytotoxicity and antibacterial potential. Saudi J Biol Sci. 2021;28:980-7. https://doi. org/10.1016/j.sjbs.2020.11.022.

17. Escobar A, Perez M, Romanelli G, Blustein G. Thymol bioactivity: A review focusing on practical Applications. Arab J Chem. 2020;13:9243-69. https://doi.org/10.1016/j.arabjc.2020.11.009.

18. Ghasemi G, Alirezalu A, Ghosta Y, Jarrahi A, Safavi SA, Abbas-Mohammadi M, Barba FJ, Munekata PES, Domínguez R, Lorenzo JM. Composition, Antifungal, Phytotoxic, and Insecticidal Activities of Thymus kotschyanus Essential Oil. Molecules. 2020;25:1152. https://doi.org/10.3390/molec ules25051152.

19. Kowalczyk A, Martyna P, Sylwia S, Agnieszka B, Izabela F. Thymol and thyme essential oil-new insights into selected therapeutic applications. Rev Mol. 2020;25:4125. https://doi.org/10.3390/molecules25184125.

20. Selvam SP, Dharini S, Puffy S, Lise K. Essential oil vapours suppress the development of anthracnose and enhance defence related and antioxidant enzyme activities in avocado fruit. Postharvest Biol Technol. 2013;81:66-72. https://doi.org/10.1016/j.postharvbio.2013.02.007.

21. Tohidi B, Rahimmalek M, Arzani A, Trindade H. Sequencing and variation of terpene synthase gene (TPS2) as the major gene in biosynthesis of thymol in different Thymus species. Phytochemistry. 2020;169: 112126. https://doi.org/10.1016/j.phytochem.2019.112126.

22. Codruta HS, Lorena F, Oliviu V, Cristina M, Doina M, Adela IC, Mirela M. Essential oil-bearing plants from balkan peninsula: promising sources for new drug candidates for the prevention and treatment of diabetes mellitus and dyslipidemia. Front Pharmacol. 2020;11:989. https://doi.org/ 10.3389/fphar.2020.00989.

23. Tariq S, Wani S, Rasool W, Shafi K, Bhat MA, Prabhakar A, Shalla AH, Rather MAA. Comprehensive review of the antibacterial, antifungal and antiviral potential of essential oils and their chemical constituents against drugresistant microbial pathogens. Microb Pathog. 2019;134: 103580. https:// doi.org/10.1016/j.micpath.2019.103580.

24. World Health Organization. http://apps.who.int/medicinedocs/en/d/ Js2200e/28.html. 2012. Accessed 3 June 2021.

25. Castillo S, Perez-Alfonso CO, Martinez-Romero D, Guillen F, Serrano M, Valero D. The essential oils thymol and carvacrol applied in the packing lines avoid lemon spoilage and maintain quality during storage. Food Control. 2014;35:132-6. https://doi.org/10.1016/j.foodcont.2013.06.052.

26. Wang CY, Wang SY, Yin J, Parry J, Yu LL. Enhancing antioxidant, antiproliferation, and free radical scavenging activities in strawberries with essential oils. J Agric Food Chem. 2007;55:6527-32. https://doi.org/10 1021/jf070429a.

27. Atress ASH, El-Mogy MM, Aboul-Anean HE, Alsanius BW. Improving strawberry fruit storability by edible coating as a carrier of thymol or calcium chloride. J Hort Sci Ornamental Plants. 2010;2:88-97.

28. Serrano M, Martınez-Romero D, Castillo S, Guillen F, Valero D. The use of antifungal compounds improves the beneficial effect of MAP in sweet cherry storage. Innov Food Sci Emerging Technol. 2005;6:115-23. https:// doi.org/10.1016/j.ifset.2004.09.001.

29. Valero D, Valverde JM, Martinez-Romero D, Guillen F, Castillo S, Serrano $M$. The combination of modified atmosphere packaging with eugenol or thymol to maintain quality, safety and functional properties of table grapes. Postharvest Biol Technol. 2006;41:317-27. https://doi.org/10 1016/j.postharvbio.2006.04.011.

30. Valverde JM, Guilleän F, Martiänez-Romero D, Castillo S, Serrano M, Valero D. Improvement of Table Grapes Quality and Safety by the Combination of Modified Atmosphere Packaging (MAP) and Eugenol, Menthol, or Thymol. J Agric Food Chem. 2005;53:7458-64. https://doi.org/10.1021/ jf050913i.
31. Haohe H, Huang C, Yin C, Khan M, Zhao H, Xu Y, Huang L, Zheng D, Qi M. Preparation and characterization of $\beta$-cyclodextrin oregano essential oil microcapsule and its effect on storage behavior of purple yam. J Sci Food Agric. 2020;100:4849-57. https://doi.org/10.1002/jsfa.10545.

32. Selcuk N, Erkan M. The effects of modified and palliflex controlled atmosphere storage on postharvest quality and composition of 'Istanbul' medlar fruit. Postharvest Biol Technol. 2015;99:9-19. https://doi.org/10. 1016/j.postharvbio.2014.07.004.

33. Khan MR, Suwanamornlert $P$, Leelaphiwat $P$, Chinsirikul W, Chonhenchob V. Quality and biochemical changes of longan (Dimocarpus longan Lour cv. Daw) fruit under different controlled atmosphere conditions. Int J Food Sci Technol. 2017;52:2163-70. https://doi.org/10. $1111 /$ ijfs.13495.

34. Dewanto V, Wu X, Adom KK, Liu RH. Thermal processing enhances the nutritional value of tomatoes by increasing total antioxidant activity. J Agric Food Chem. 2002;50:3010-4. https://doi.org/10.1021/jf0115589.

35. Duan X, Su X, You Y, Qu H, Li Y, Jiang Y. Effect of nitric oxide on pericarp browning of harvested longan fruit in relation to phenolic metabolism. Food Chem. 2007;104:571-6. https://doi.org/10.1016/j.foodchem.2006. 12.007.

36. Jiang Y. Purification and some properties of polyphenol oxidase of longan fruit. Food Chem. 1999;66:75-9.

37. Zhang Z, Pang X, Xuewu D, Ji Z, Jiang Y. Role of peroxidase in anthocyanin degradation in litchi fruit pericarp. Food Chem. 2005;90:47-52. https://doi.org/10.1016/j.foodchem.2004.03.023.

38. Bradford MM. A rapid and sensitive method for the quantitation of microgram quantities of protein utilizing the principle of protein-dye binding. Analy Biochem. 1976;72:248-54. https://doi.org/10.1016/ 0003-2697(76)90527-3.

39. Geransayeh M, Sepahvand S, Abdossi V, Nezhad RA. Effect of thymol treatment on decay, postharvest life and quality of strawberry (Fragaria ananassa) Fruit cv. 'Gaviota. Int J Agron Agric Res. 2015;6:151-62.

40. Awad AHR, Parmar A, Ali MR, El-Mogy MM, Abdelgawad KF. Extending the Shelf-Life of Fresh-Cut Green Bean Pods by Ethanol, Ascorbic Acid, and Essential Oils. Foods. 2021;10:1103. https://doi.org/10.3390/foods 10051103.

41. Marino M, Bersani C, Comi G. Impendance measurements to study the antimicrobial activity of essential oils from Lamiaceae and Compositae. Int J Food Microbiol. 2001;67:185-7. https://doi.org/10.1016/s01681605(01)00447-0.

42. Poonam K, Neha A, Apurva C, Rashmi G, Vikas P, Poluri KM, Prasad R. Delineating the Biofilm Inhibition Mechanisms of Phenolic and Aldehydic Terpenes against Cryptococcus neoformans. ACS Omega. 2019;4:17634-48. https://doi.org/10.1021/acsomega.9b01482.

43. Nazar FN, Videla EA, Marin RH. Thymol supplementation effects on adrenocortical, immune and biochemical variables recovery in Japanese quail after exposure to chronic heat stress. Animal. 2019;13:31825. https://doi.org/10.1017/S175173111800157X

44. Kryvtsova MV, Salamon I, Koscova J, Bucko D, Spivak M. Antimicrobial, antibiofilm and biochemical properties of Thymus vulgaris essential oil against clinical isolates of opportunistic infections. Biosyst Divers. 2019;27:270-5. https://doi.org/10.15421/011936.

45. Perez AP, Perez N, Lozano CMS, Altube MJ, de Farias MA, Portugal RV, Buzzola F, Morilla MJ, Romero EL. The anti MRSA biofilm activity of Thymus vulgaris essential oil in nanovesicle. Phytomedicine. 2019;57:33951. https://doi.org/10.1016/j.phymed.2018.12.025.

46. Abd-Alla MA, Abd-El-Kader MM, Abd-El-kareem F, El-Mohamedy RSR. Evaluation of lemongrass, thyme and per acetic acid against gray mold of strawberry fruits. J Agri Technol. 2011;7:1775-87.

47. Meer H, Iram S, Ahmad I, Fateh FS, Kazmi MR. Identification and characterization of postharvest fungal pathogens of mango from domestic markets of Punjab. Int J Agron Plant Prod. 2013:4:650-8.

48. Inouye S, Abe S, Yamaguchi H, Asakura M. Comparative study of antimicrobial and cytotoxic effects of selected essential oils by gaseous and solution contacts. Int J Aromather. 2003;13:33-41. https://doi.org/ 10.1016/S0962-4562(03)00057-2.

49. Tripathi P, Dubey NK, Shukla AK. Use of some essential oils as postharvest botanical fungicides in the management of grey mould of grapes caused by Botrytis cinerea. World J Microbiol Biotechnol. 2008;24:39_ 46. https://doi.org/10.1007/s11274-007-9435-2. 
50. Goni P, Lopez P, Sanchez C, Gomez-Lus R, Becerril R, Nerın C. Antimicrobial activity in the vapour phase of a combination of cinnamon and clove essential oils. Food Chem. 2009;116:982-9. https://doi.org/10. 1016/j.foodchem.2009.03.058.

51. Akbari E, Gholami M, Ghobad C. Shelf-life and quality attributes in fresh-cut pear cv Shahmive treated with different kinds of antioxidants. J Food Sci Technol. 2019. https://doi.org/10.1007/s13197-019-03868-6.

52. Kevin PA, Suziat AD, Mahmoud AS. Comprehensive assessment of antioxidant activity of essential oils. J Food Sci. 2012;77:839-43. https:// doi.org/10.1111/j.1750-3841.2012.02795.x.

53. Wu XT, Guo XN, Zhu KX. Inhibition of L-Cysteine on the Browning of Fresh Wet Noodles. Foods. 2021;10:1156. https://doi.org/10.3390/foods 10061 156.
54. Liu WT, Chu CL, Zhou T. Thymol and acetic acid vapors reduce post harvest brown rot of apricot and plums. Hort Sci. 2002;37:151-6. https:// doi.org/10.21273/HORTSCI.37.1.151.

\section{Publisher's Note}

Springer Nature remains neutral with regard to jurisdictional claims in published maps and institutional affiliations.

\section{Submit your manuscript to a SpringerOpen ${ }^{\circ}$ journal and benefit from:}

- Convenient online submission

- Rigorous peer review

- Open access: articles freely available online

- High visibility within the field

- Retaining the copyright to your article

Submit your next manuscript at $\boldsymbol{\nabla}$ springeropen.com 